\title{
MANAJEMEN KONFLIK PERSPEKTIF PENDIDIKAN ISLAM
}

\author{
YUSNIA BINTI KHOLIFAH \\ Dosen pada STAI Ma'arif Kendal - Ngawi - Indonesia \\ Email: yusnia033091@gmail.com
}

\begin{abstract}
Conflict is inevitable and will surely be present in every person's life or the life of an organization. Viewing conflict can be from two angles, each point of view will have different consequences and will even be opposite. When conflicts are seen as positive in the sense that they are seen as learning, conflict will become a force for progress. But on the contrary if the conflict is seen as something that is not good or negative then the conflict will become a weakness that can cause stress, division and even hostility. Looking at these two points of view when someone is told to choose, it will choose the good, that is, conflict is seen positively, because actually everyone does not like division. But this is not easy because in reality everyone tends to be emotional when facing a conflict that ultimately has a negative impact. Therefore we need a way to manage a conflict that comes so that conflict becomes a positive thing. Islamic education teaches various ways on how to deal with conflict. Because in fact there is a difference that is considered as a trigger for the emergence of conflict is a blessing.
\end{abstract}

\section{Abstrak}

Konflik tidak bisa dihindari dan memandang konflik bisa dari dua sudut yang masing-masing sudut pandang akan memiliki konsekuensi yang berbeda bahkan akan berlawanan. Ketika konflik dipandang sebagai suatu pembelajaran maka konflik akan menjadi kekuatan untuk suatu kemajuan. Namun konflik juga akan menjadi suatu kelemahan yang bisa menimbulkan stress, perpecahan bahkan permusuhan. Melihat kedua sudut pandang tersebut ketika seseorang disuruh memilih maka akan memilih yang baik yaitu konflik dipandang secara positif, karena sejatinya setiap orang tidak menyukai perpecahan. Tetapi hal tersebut tidaklah mudah karena kenyataannya setiap orang cenderung emosi ketika menghadapi suatu konflik yang akhirnya berdampak kurang baik. Oleh karena itu diperlukan suatu cara untuk mengelola sebuah konflik yang datang sehingga konflik menjadi suatu hal yang positif. Pendidikan Islam mengajarkan berbagai cara bagaimana dalam menghadapi konflik. Karena sesungguhnya adanya perbedaan yang dianggap sebagai pemicu munculnya konflik merupakan suatu rahmat.

\section{Kata Kunci: Manajemen Konflik, Pendidikan Islam}




\section{A. Pendahuluan}

Peran para stakeholders dan para anggota organisasi dituntut semakin partisipatif. Peran partisipasi dari para anggota organisasi sangat diperlukan dalam menciptakan kreativitas dan inovasi demi laju organisasi dalam mencapai tujuannya. Pada proses pencapaian tujuan yang partisipatif ini sangat mungkin terjadi adanya benturan antar anggota dalam organisasi tersebut, baik yang bersifat langsung ataupun terbuka, maupun tidak langsung ataupun bersifat tertutup. Perbedaan tersebut menyangkut implementasi kebijakan dalam organisasi, yang dalam konteks pembahasan ini merupakan suatu hal yang wajar. Benturan-benturan dari masing-masing perbedaan, akhirnya akan bermuara pada suatu kondisi yang man disebut dengan konflik.

Secara umum setiap orang punya kecenderungan akan menghindari konflik, meskipun dalam kenyataannya semua manusia pasti akan mengalami konflik, baik dengan dirinya sendiri maupun orang lain. Begitu juga dalam berorganisasi, akan tetapi sayangnya beranggapan bahwa timbulnya konflik bisa memunculkan kegagalan pencapaian tujuan sampai organisasi terpecah belah merupakan sudut pandang yang paling umum selama ini terjadi. Seharusnya konflik harus dipandang secara positif bahwa konflik sebagai aspek penting yang menentukan maju atau mundurnya sebuah organisasi. Oleh karena itu bukan menghindari konflik yang sudah pasti akan terjadi dalam organisasi tetapi yang lebih penting lagi adalah bagaimana mengelola sebuah konflik yang terjadi dalam organisasi tersebut.

Setiap masalah pasti akan ada solusinya, tidak ada masalah yang tidak bisa diselesaikan. Begitu juga konflik, berbagai cara diusahakan dalam mengelola konflik sehingga dengan adanya konflik yang pasti datang bukan membawa kepada perpecahan atau kebencian, justru dengan adanya konflik akan menjadi suatu kekuatan untuk mencapai kemajuan. Islam mengajarkan suatu kedamaian bukan permusuhan yang rata-rata terjadi akibat adanya konflik yang tidak dikelola dengan baik dan positif. Sehingga mengelola konflik menjadi sangat penting demi mencapai kemajuan suatu organisasi. Selain itu dengan konflik yang dikelola dengan baik akan memberikan dampak yang positif bagi setiap orang yang mengalami konflik. Tidak akan mudah frustasi atau stress, tidak mudah memicu timbulnya kebencian antar sesama, tetapi dengan adanya konflik yang terjadi justru bisa memberikan banyak kemanfaatan, menambah kedewasaan dengan memahami akan ada hikmah disetiap kejadian, menjadi semangat untuk lebih maju dan berprestasi.

Agar konflik dapat dikelola dengan baik perlu juga pemahaman mengenai sumber-sumber pemicu terjadinya konflik serta pemahaman terhadap cara-cara mengatasinya. Dalam hal ini pendidikan Islam 
memandang konflik bukan suatu titik lemah, melainkan sesuatu yang bisa menjadi kekuatan. Oleh karena itu Islam mengajarkan banyak cara dalam mengelola suatu konflik agar konflik dapat dianggap suatu bentuk rahmat bukan awal terjadinya perpecahan.

\section{B. Hakikat Konflik}

Konflik berasal dari kata configure atau conficium yang berarti benturan, yang menunjuk pada semua bentuk benturan, tabrakan, ketidaksesuaian, pertentangan, perkelahian, oposisi, dan interaksiinteraksi yang bersifat antagonis. ${ }^{1}$ Secara makna konflik diartikan sebagai adanya reaksi yang muncul dari seseorang karena merasa terancam, baik teritorialnya maupun kepentingannya, dengan menggunakan kekuatan untuk mempertahankan teritorial atau kepentingan tersebut. ${ }^{2}$ Sementara Robbins menyebutkan bahwa konflik merupakan suatu proses interaksi yang terjadi akibat adanya ketidaksesuaian antara dua pendapat yang akan berpengaruh terhadap pihak-pihak yang terlibat baik pengaruh positif maupun pengaruh negatif. ${ }^{3}$

Mengenai definisi konflik Afzalur Rahim menyebutkan bahwa konflik merupakan interaksi yang termanifestasikan dari sikap ketidakcocokan, pertentangan atau perbedaan antara intentitas sosial seperti individu-individu, kelompok-kelompok atau organisasiorganisasi. ${ }^{4}$ Sedangkan Wahyosumidjo mengatakan bahwa konflik merupakan segala macam bentuk hubungan antara manusia yang mengandung sifat berlawanan. ${ }^{5}$

Berbagai istilah konflik menyebutkan bahwa konflik merupakan perbedaan pendapat, persaingan ataupun permusuhan. Akan tetapi berbeda pendapat tidak selalu berarti berbeda keinginan. Sedangkan konflik sendiri bersumber dari suatu keinginan, oleh karena itu berbeda pendapat tidak selalu berarti konflik. Tetapi jika perbedaan pendapat tidak dikelola secara baik akan dapat menimbulkan konflik dan pertentangan yang membahayakan, yang pada akhirnya mengakibatkan hilangnya kekuatan persatuan dan kesatuan. Persaingan juga tidak sama dengan konflik, akan tetapi persaingan sangat mudah untuk menjurus ke ranah konflik. Begitu juga permusuhan bukan berarti konflik, orang yang saling bermusuhan bisa saja mereka tidak berada dalam keadaan konflik,

\footnotetext{
${ }^{1}$ Sulistyorini dan Fathurrohman Muhammad, Esensi Manajemen Pendidikan Islam Pengelolaan Lembaga untuk Meningkatkan Kualitas Pendidikan Islam (Yogyakarta: Teras, 2014), 296.

${ }^{2}$ Asnawir, Manajemen Pendidikan (Padang: IB Press, 2006), 319.

${ }^{3}$ Robbins, SP. Organizational Behaviour, (Prentice Hall, Siding), 1979, 23.

${ }^{4}$ Afzalur Rahim, Managing Conflict in Organization, (Praeger, New York, 1986),113.

5 Wahyosumidjo, Kepemimpinan Kepala Sekolah, Tinjauan Teoretik dan Permaslahannya, (Raja Gafindo Persada, Jakarta, 2002), 152.
} 
begitu juga sebaliknya orang yang memiliki konflik bisa saja tidak memiliki rasa permusuhan.

Oleh karena itu dapat disimpulkan bahwa konflik merupakan adanya ketidaksesuaian atau ketidakcocokan mengenai sudut pandang yang bersumber dari keinginan seseorang atau kelompok dalam menyikapi suatu masalah yang kemudian menimbulkan adanya pengaruh. Pengaruh yang ditimbulkan tidak hanya menjurus pada hal negatif, tetapi bisa juga menjadi hal positif. Sebagaimana pendapat Allport yang dikutip Hanson menyatakan semakin banyak sarjana sosial yang memaparkan bahwa konflik itu sendiri bukan kejahatan, tetapi lebih merupakan suatu gejala yang memiliki pengaruh-pengaruh konstruktif atau destruktif, tergantung pada manajemennya. ${ }^{6}$ Oleh karena itu pengaruh positif atau negatif dari adanya konflik tergantung dari bagaimana memanaj atau mengelolanya.

Konflik yang terjadi dalam suatu organisasi dapat menjadi energi kuat yang diperlukan untuk kemajuan dan perkembangan organisasi serta dapat dijadikan alat untuk suatu perubahan jika konflik dikelola dengan baik, namun sebaliknya akan dapat menurunkan kinerja jika tidak dikelola atau dikendalikan secara baik. Disadari atau tidak, konflik akan selalu ada kapan, dan dimana saja. Hal penting yang dilakukan adalah bagaimana mengelola serta mengatasi terjadinya konflik yang tidak sehat tersebut. Sehubungan dengan itu pimpinan organisasi atau kelompok yang mengalami konflik harus bertanggung jawab untuk mengindentifikasi sumber-sumber dan jenis-jenis dari konflik tersebut sedini mungkin, serta menganalisa akibat-akibat yang mungkin akan timbul. Selain itu juga harus mengetahui kekuatan-kekuatan dan kelemahan untuk dapat menentukan langkah-langkah preventif yang dilakukan secara tepat.

Konflik muncul karena dipicu oleh beberapa sumber. Dalam hal ini Wahjosumidjo menyebutkan konflik yang terjadi selalu bersumber pada manusia dan perilakunya, disamping pada struktur organisasi dan komunikasi. ${ }^{7}$ Meskipun ada beberapa sumber konflik, tetapi yang sering menyebabkan konflik adalah perilaku manusia. Oleh karenanya, sering terjadi, masalah yang sebenarnya sederhana, tetapi karena prilaku manusianya yang tidak sehat, akhirnya menjadi masalah yang besar. Sementara Gibson menyebutkan bahwa ada tiga hal yang bisa merangsang timbulnya konflik dalam hubungan antar anggota dalam suatu kelompok, yaitu perkara tugas, hubungan, dan proses. ${ }^{8}$

\footnotetext{
${ }^{6}$ Hanson, Educational Administration and Organizational Behavior, (Allyn and Bacon, Boston, 1990), 273.

${ }^{7}$ Wahjosumidjo, Kepemimpinan,נ,..152.

8 James Gibson, Organization, Behavior, Sructures, Processor, (Boston: Mc Grawhill, 2004), 252253.
} 
Konflik bisa terjadi karena salah satu atau masing-masing pihak merasa dirugikan, baik secara material maupun non-material. Dalam hal ini Mulyasa menjelaskan beberapa penyebab munculnya konflik, antara lain: ${ }^{9}$

1. Perbedaan pendapat. Konflik dapat terjadi sebab adanya perbedaan pendapat dan masing-masing merasa paling benar. Apabila perbedaan pendapat ini meruncing dan mencuat ke permukaan, maka akan menimbulkan ketegangan.

2. Salah paham. Adanya kesalahpahaman (misunderstanding), misalnya tindakan seseorang yang bertujuan baik, akan tetapi dianggap merugikan oleh pihak lain. Kesalahpahaman ini akan menimbulkan adanya rasa kurang nyaman, kurang simpati dan kebencian.

3. Salah satu atau masing-masing pihak merasa dirugikan. Konflik dapat terjadi karena tindakan salah satu pihak yang dianggap merugikan pihak lain atau masing-masing pihak merasa dirugikan. Pihak yang dirugikan merasa kesal, kurang nyaman, kurang simpati sehingga menimbulkan kebencian. Dan pada akhirnya dapat menimbulkan konflik yang mengakibatkan kerugian baik secara materi, moral maupun sosial.

4. Perasaan yang terlalu sensitif. Konflik dapat terjadi karena perasaan yang terlalu sensitif, mungkin tindakan seseorang adalah wajar, tetapi karena pihak lain terlalu sensitif maka dianggap merugikan, dan menimbulkan konflik, walaupun secara etika tindakan ini tidak termasuk perbuatan yang salah.

Setelah mengetahui penyebab adanya konflik, penting juga mengetahui jenis-jenis konflik, hal tersebut diperlukan sebagai wacana bagaimana seharusnya mengelola konflik tersebut. Mengenai beberapa jenis konflik yang terjadi pada suatu organisasi atau lembaga Mulyasa menyebutkan bahwa konflik dalam suatu lembaga dapat terjadi dalam semua tingkatan, baik intrapersonal, interpersonal, intragroup, intergroup, intraorganisasi, maupun interorganisasi. ${ }^{10}$

1. Konflik intrapersonal, yaitu konflik internal yang terjadi dalam diri seseorang. Konflik ini akan terjadi ketika individu harus memilih dua atau lebih tujuan yang saling bertentangan sehingga merasa bimbang mana yang harus dipilih untuk dilakukan. Misalnya, konflik antara tugas kerja dengan acara pribadi. Konflik intrapersonal ini juga bisa disebabkan oleh tuntutan tugas yang melebihi kemampuan.

\footnotetext{
${ }_{9}^{9}$ Mulyasa, Menjadi Kepala Sekolah Profesional, Dalam Konteks Menyukseskan MBS dan KBK, (Bandung: PT Remaja Rosdakarya, 2003), 241-242.

10 Mulyasa, Menjadi Kepala Sekolah Profesional,נ,נ, , 243-244.
} 
2. Konflik interpersonal, yaitu konflik yang terjadi antar individu. Konflik ini terjadi ketika adanya perbedaan tentang isu tertentu, tindakan dan tujuan dimana hasil bersama sangat menentukan.

3. Konflik Intragroup, yaitu konflik antar anggota dalam satu group dalam satu kelompok. Setiap kelompok bisa mengalami konflik substantif maupun efektif. Konflik substantif terjadi disebabkan adanya latar belakang keahlian yang berbeda, ketika anggota dari satu komite menghasilkan kesimpulan yang berbeda atas data yang sama. Sedangkan konflik efektif terjadi disebabkan adanya tanggapan emosional terhadap suatu situasi tertentu. Contoh konflik intragroup misalnya konflik yang terjadi pada beberapa dosen dalam musyawarah dosen prodi tertentu.

4. Konflik intergroup, merupakan konflik yang terjadi antar kelompok. Konflik intergroup terjadi disebabkan adanya saling ketergantungan, perbedaan persepsi, perbedaan tujuan. Misalnya konflik antara kelompok guru seni budaya dengan kelompok guru fisika. Kelompok guru seni budaya berpresepsi bahwa dalam pembelajaran lagu tertentu dan melatih pernafasan perlu disuarakan dengan keras, sementara kelompok guru fisika merasa terganggu sebab para peserta didiknya tidak konsentrasi dalam belajar.

5. Konflik intraorganisasi, merupakan konflik yang terjadi antar bagian dalam suatu organisasi. Misalnya konflik antara bidang LPM dengan bidang kemahasiswaan. Konflik intraorganisasi meliputi empat sub jenis, yaitu:

a. Konflik vertikal, yang terjadi antara pimpinan dan bawahan yang tidak sependapat tentang cara terbaik dalam menyelesaikan sesuatu. Misalnya antara ketua program studi sekolah dengan dosen.

b. Konflik horizontal, yang terjadi antara departemen yang memiliki hirarki yang sama dalam organisasi, misalnya konflik antar dosen, konflik antar karyawan.

c. Konflik lini-staf, terjadi karena adanya perbedaan persepsi tentang keterlibatan staf dalam proses pengambilan keputusan oleh manajer lini. Misalnya konflik antara kepala jurusan dengan tenaga administrasi.

d. Konflik peran, merupakn konflik yang terjadi karena seseorang mempunyai lebih dari satu peran. Misalnya kepala jurusan menjabat sebagai ketua program studi. Sementara menurut Wahjosumidjo ada empat macam konflik peran yaitu sebagai berikut:

1) Konflik yang muncul dari seorang penentu peran (intra sender role conflict). 
2) Konflik yang muncul dari dua atau lebih penentu peran (intersender role conflict).

3) Konflik yang terjadi karena adanya benturan dua peran yang dimiliki oleh seseorang (interrole conflict).

4) Konflik yang terjadi antara masalah kewajiban dan masalah pribadi seseorang (person role conflict). ${ }^{11}$

e. Konflik interorganisasi, yaitu konflik yang terjadi antar organisasi. Konflik interorganisasi terjadi karena mereka saling memiliki ketergantungan satu sama lain, konflik terjadi pada tindakan suatu organisasi yang menyebabkan dampak negatif terhadap organisasi lain. Misalnya, konflik yang terjadi antara lembaga perguruan tinggi dengan salah satu organisasi masyarakat. Semua bentuk-bentuk konflik tersebut akan menimbulkan konsekuensi.

\section{Pengaruh adanya Konflik dalam Pendidikan Islam}

Ada dua perbedaan pandangan terkait akibat atau pengaruh adanya konflik. Pandangan pertama beranggapan bahwa konflik merupakan suatu gejala yang membahayakan dan pertanda instabilitas lembaga atau organisasi. Implikasinya, manakala suatu lembaga pendidikan sering memiliki konflik, berarti lembaga tersebut semakin tidak stabil dan rentan akan bahaya sehingga harus segera diatasi. Sebaliknya, pandangan kedua beranggapan bahwa konflik itu menunjukkan adanya dinamika dalam organisasi atau lembaga, yang bisa mengantarkan pada kemajuan. Apabila dalam organisasi atau lembaga tidak ada konflik, justru ini menunjukkan tidak ada dinamika sama sekali yang berarti jauh dari realisasi kemajuan, kendatipun konflik juga harus dikelola dengan baik.

Pendapat pertama yang beranggapan bahwa konflik merupakan bahaya yang suatu saat bisa mengancam keberadaan dan kelangsungan organisasi atau lembaga. Sementara pendapat kedua beranggapan bahwa konflik adalah tantangan yang dapat dijadikan rangsangan untuk memacu kemajuan lembaga atau organisasi. Pendapat kedua ini memberikan respon secara positif terhadap adanya konflik. Namun kedua pendapat tersebut dapat disatukan dengan kesepakatan bahwa perlu adanya manajemen konflik, yaitu bagaimana mengelola suatu konflik.

Mengenai akibat atau pengaruh adanya konflik Mulyasa mengemukakan secara rinci dan jelas konsekuensi sebuah konflik, baik secara positif ataupun negatif. Konsekuensi positif antara lain: ${ }^{12}$

a. Menimbulkan kemampuan instropeksi diri, adanya konflik dapat dirasakan oleh pihak lain, dengan mengetahui sebab-sebab terjadinya konflik mereka akan mampu melakukan instropeksi diri.

11 Wahjosumidjo, Kepemimpinan. ...153-154.

${ }^{12}$ Mulyasa, Menjadi Kepala,... 245-246. 
b. Meningkatkan kinerja, konflik dapat menjadi cambuk bagi seseorang sehingga menyebabkan peningkatan kinerja. Konflik dapat mendorong individu untuk menunjukkan kepada orang lain bahwa dia mampu meningkatkan kinerjanya dengan baik.

c. Pendekatan yang lebih baik, konflik dapat menimbulkan kejutan karena kehadirannya yang sering tidak terduga, sehingga setiap orang berusaha lebih hati-hati dalam berinteraksi dan menyebabkan hubungan yang lebih baik.

d. Mengembangkan alternatif yang lebih baik. Konflik bisa menimbulkan hal-hal yang merugikan pihak tertentu jika terjadi antara satu atasan dengan bawahan, misalnya tidak memberikan suatu jabatan atau sering menjadi tantangan untuk mengembangkan solusi yang lebih baik.

Sedangkan konsekuensi negatifnya adalah:

a. Subjektif dan emosional, pada umumnya pendapat pihak yang sedang berkonflik satu sama lain sudah tidak objektif lagi dan bersifat emosional.

b. Apriori, jika konflik sudah meningkat bukan hanya subjektif dan emosional saja yang muncul tetapi dapat menyebabkan apriori, sehingga pendapat pihak lain selalu dianggap salah dan dirinya selalu benar.

c. Saling menjatuhkan, konflik yang berkelanjutan bisa mengakibatkan saling membenci dan mendorong individu menjatuhkan lawan, misalnya fitnah, menghambat dan mengadu domba.

d. Stres, konflik yang berkepanjangan tidak hanya menurunkan kinerja tetapi juga menyebabkan terjadinya stress, karena konflik yang berkepanjangan menimbulkan ketidakseimbangan fisik dan psikis, sebagai bentuk reaksi terhadap tekanan yang intensitasnya sudah terlalu tinggi.

e. Frustasi, konflik dapat memacu berbagai pihak yang terlibat untuk berprestasi, tetapi jika konflik tersebut sudah pada tingkat yang cukup parah dan diantara pihak-pihak yang terlibat ada yang lemah mentalnya bisa menimbulkan frustasi.

Dari uraian diatas, dapat disimpulkan bahwa ada keterkaitan antara sumber konflik dan stress itu sendiri yaitu berasal dari perilaku dan pikiran manusia. Suatu masalah bisa cepat selesai atau bahkan semakin lebih besar permasalahannya tergantung dengan perilaku manusia bagaimana dalam menyikapinya. Masalah yang sederhana pun bisa menjadi lebih besar, jika perilaku manusia dalam menyikapinya kurang sehat, begitu juga sebaliknya. Dan perilaku manusia sering juga dipengaruhi oleh pola pikir manusia, pola pikir yang positif akan 
menimbulkan perilaku yang sehat, dan sebaliknya pola pikir yang negatif akan menimbulkan perilaku yang kurang sehat.

Pada lembaga pendidikan Islam konflik sering kali terjadi, baik konflik intrapersonal, interpersonal, intragroup, intergroup, intraorganisasi, bahkan interorganisasipun juga bisa terjadi. Pengaruh adanya suatu konflik sebagaimana disampaikan diatas bahwa konflik bisa berpengaruh terhadap hal negatif maupun positif. Begitu juga dalam lembaga pendidikan Islam, dengan adanya dampak positif maka justru akan bisa mendukung berbagai proses dalam mencapai visi, misi dan tujuan dari lembaga pendidikan tersebut, akan tetapi untuk dampak negatif yang didapat maka akan dapat mengganggu bahkan menghambat apa yang menjadi visi, misi dan tujuan dari lembaga pendidikan. Oleh karenanya dengan adanya konflik yang berdampak negatif ini perlu di manaj atau dikelola secara baik sehingga tidak sampai menimbulkan hal yang lebih buruk yang bisa menimbulkan kehancuran suatu lembaga pendidikan Islam.

Pihak yang terlibat konflik seringkali menjadi mudah emosi, mudah marah yang kemudian saling membenci dan saling menjatuhkan, mencari pembelaan dari sekelompok teman yang sampai akhirnya menimbulkan konflik antar kelompok, satu sama lain saling menggunjing (Ghibah), mencaci yang semakin mengarah ke ranah dosa. Konflik yang berkepanjangan dan tidak segera diatasi akan membuat pihak yang berkonflik memiliki sikap apriori, sombong yang selalu merasa dirinya paling benar. Konflik yang berkepanjangan juga bisa menyebabkan stress dan frustasi, orang frustasi menunjukkan bahwa dia lupa ada Allah yang Maha Pengasih dan Penyayang tempat berserah diri dari segala masalah, dan Allah tidak akan memberikan beban atau cobaan melebihi kemampuannya. Dengan tidak menyadari adanya Allah yang selalu ada buat hambanya, akan membuat seseorang menjadi jauh dari hal-hal positif dan sebaliknya akan semakin dekat ke hal-hal yang negatif. Oleh karena itu konflik yang tidak berkesudaahan akan memungkinkan membawa pihak yang berkonflik melaju ke ranah dosa.

Jika pihak yang berkonflik sudah mulai terganggu jiwanya, mulai mudah emosi, menjadi sombong dan sebagaimana yang sudah disampaikan diatas, maka akan mengganggu kinerjanya, tidak konsentrasi dalam mengajar, dan mengerjakan tugas-tugas lainnya. Sehingga akan mengganggu proses manajemen dalam mencapai tujuan lembaga. Hal inilah salah satu yang dikatakan bisa menghambat apa yang menjadi visi, misi dan tujuan dari suatu lembaga pendidikan Islam. Dampak negatif dari adanya konflik perlu dikelola dengan baik sesuai dengan ajaran Islam, karena sesungguhnya setiap konflik pasti bisa diatasi sehingga tidak sampai terjerumus ke arah dosa. 


\section{Mengelola Konflik Perspektif Pendidikan Islam}

Perbedaan tak selamanya berujung konflik yang mengarah kepada hal negatif, sebagaimana yang sudah disampaikan diatas. Diperkuat lagi dengan adanya maqolah:

$$
\text { اختلا ف امتي رحمة }
$$

Perbedaan Pendapat dikalangan umatku adalah rahmat

Bahwa idealnya adanya perbedaan pendapat justru harus bisa menghasilkan hal positif. Apabila terjadi perbedaan pendapat tetapi mengarah pada konflik terbuka berarti ada hal-hal yang kontraproduktif yang terkait dengan pendapat itu. Dalam menghadapi perbedaan pendapat yang mengarah kepada konflik yang berujung pada hal negatif, Abuddin Nata memandang perlunya dikembangkan beberapa etika sebagai berikut:

1. Melihat perbedaan sebagai suatu hal yang harus diterima.

2. Menyadari bahwa pendapat yang disampaikan seseorang mungkin mengandung kebenaran atau kesalahan.

3. Bersikap terbuka, mau menerima pendapat, saran dan kritik orang lain karena mungkin pendapat kita yang salah.

4. Bersikap objektif, lebih berorientasi mencari kebenaran, bukan mencari pembenaran.

5. Tidak memandang perbedaan pendapat sebagai pertentangan atau permusuhan, akan tetapi memandang sebagai khazanah dan kekayaan yang berguna untuk memecahkan berbagai masalah.

6. Menjunjung tinggi nilai-nilai yang kemaslahatan seperti persaudaraan, kejujuran, keadilan, kebenaran dan lain sebagainya. ${ }^{13}$

Jika adanya perbedaan pendapat yang mengarah pada konflik tidak dapat dibendung, maka gejala seperti ini harus segera diatasi. Sebagaimana Allah berfirman:

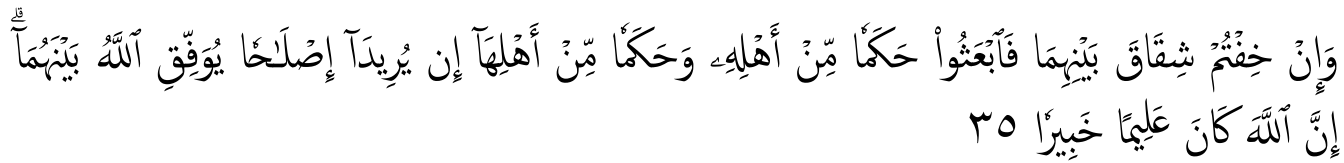

"Dan jika kamu khawatirkan ada persengketaan antara keduanya, maka kirimlah seorang hakam dari keluarga laki-laki dan seorang hakam dari keluarga perempuan. Jika kedua orang hakam itu bermaksud mengadakan perbaikan, niscaya Allah memberi taufik kepada suami-isteri itu. Sesungguhnya Allah Maha Mengetahui lagi Maha Mengenal" (Surat As Syura ayat 35)

13 Abudin Nata, Manajemen Pendidikan Mengatasi Kelemahan Pendidikan Islam di Indonesia, (Jakarta: Perdana Media, 2003), Hlm. 239. 
Ayat diatas memberikan pemahaman bahwa pertama, anjuran untuk segera menyelesaikan konflik sedini mungkin. Kedua, menyelesaikan konflik melalui mediator yang disebut hakam. Ketiga, mediator/hakam merupakan sosok yang benar-benar bisa diteladani. Keempat, mediator/hakam berjumlah dua orang yang mewakili masingmasing pihak. Terakhir, ada keinginan yang kuat untuk melakukan ishlah/penyelesaian konflik dari masing-masing pihak.

Ayat tersebut ditujukan dalam menyelesaikan konflik pada lembaga pendidikan keluarga. Namun pesan resolusi konflik dalam ayat tersebut dapat diterapkan pada lembaga yang lebih luas, seperti lembaga pendidikan formal yaitu sekolah atau madrasah, perguruan tinggi dan pesantren. Sementara itu, tahapan resolusi konflik yang sering dilakukan dalam lembaga pesantren antara lain, silaturahmi sebagai proses pencegahan konflik, mengadakan bahts al masaail sebagai proses penekanan dan penyekatan konflik, tabaayun sebagai bentuk proses pengaturan dan penyekatan konflik, hakam atau moderator sebagai proses pelembagaan konflik, yang terakhir yaitu ishlah sebagai proses akhir penyelesaian konflik. ${ }^{14}$

Islam juga memberikan konsep ukhuwah sebagai bentuk dari resolusi konflik. Dijelaskan bahwa dalam menyelesaikan sebuah konflik haruslah memperhatikan dimensi uluhiyah (ketuhanan) serta dimensi insaniyah (kemanusiaan). ${ }^{15}$ Sebagaimana firman Allah dalam surat An Nisa' ayat 59:

Kemudian dalam mengelola stress yang sering dialami akibat adanya konflik, Allah SWT melalui firmannya Al Qur'an telah menyampaikan pesan kepada kita agar mengendalikan emosi sedih dan gembira. Tidak semestinya kita larut dalam kesedihan atau tekanantekanan psikologis karena kehilangan sesuatu yang kita cintai atau karena tidak bisa memiliki apa yang kita harapkan. Begitu pula kita tidak boleh larut dengan kesombongan, keangkuhan, riya atau membanggabanggakan diri jika mendapatkan kesuksesan, jabatan, keunggulan atau prestise. Sebab segala gangguan dan musibah yang menimpa diri kita ataupun cobaan berupa kesenangan atau kebaikan yang kita raih telah termaktub dalam Lauh Mahfuzh dan ilmu Allah SWT.

\footnotetext{
${ }^{14}$ Farchan dan Syarifudin, Titik...., 174-196.

15 Said Aqil Siroj, Islam Sumber Inspirasi Budaya Nusantara Menuju Masyarakat Mutamaddin, cetakan ke II (Jakarta Pusat: LTN NU, 2015), 38.
} 


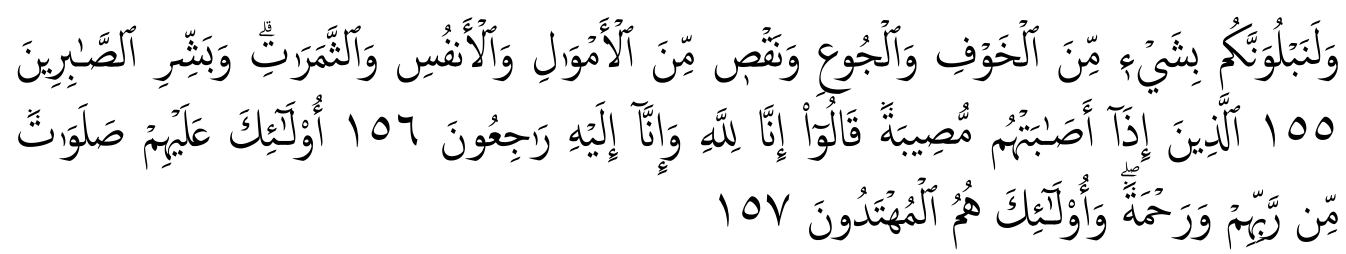

"Dan sesungguhnya Kami berikan cobaan kepadamu, dengan sedikit ketakutan, kelaparan, kekurangan harta, jiwa dan buah-buahan. Dan berikanlah berita gembira kepada orang-orang yang sabar, yaitu orangorang yang apabila ditimpa musibah, mereka mengucapkan, "innalillahi wa innalillahirooji'uun ". Mereka itulah yang mendapat keberkatan yang sempurna dan rahmat dari Tuhan mereka, dan mereka itulah orang-orang yang mendapat petunjuk.

Dari ayat di atas, secara umum, Allah berpesan agar kita mampu menguasai, mengendalikan dan mengontrol emosi atas semua musibah dan cobaan yang terjadi pada diri kita, anak- anak, pekerjaan, keluarga, harta atau lingkungan sekitar kita. Ini maknanya apapun yang terjadi pada diri kita hendaknya tidak membuat kita sampai tertekan, jatuh sakit, dan akhirnya memicu stress.

Dalam menghadapai berbagai keberagaman Ahlussunnah Wal Jamaah (Aswaja) mengajarkan penerapan sikap Tawassuth dan I'tidal (tengah-tengah), Tasammuh (toleransi), Tawazzun (keseimbangan), dan Amar Ma'ruf Nahi Munkar (mengajak kepada kebaikan dan mencegah kemunkaran) ${ }^{16}$. Konsep tersebut juga bisa sebagai solusi dalam menghadapi adanya suatu konflik dalam suatu kelompok, baik pada organisasi, dunia bisnis maupun dunia pendidikan. Tawassuth dan I'tidal sebagai sebuah sikap keberagaman yang tidak terjebak pada titik-titik konflik yang terjadi, dimana sikap ini mampu menjemput setiap kebaikan dari berbagai sudut pandang. Dengan memberikan apresisasi kebaikan dari berbagai sudut pandang, maka posisi dengan sikap seperti ini tetap berada di tengah-tengah, sehingga tidak akan memicu terjadinya konflik yang semakin panas, justru akan memungkinkan konflik semakin mereda.

Tasammuh sebagai sebuah sikap yang menerima kehidupan sebagai sesuatu yang beragam. Keberagaman menutut adanya sebuah sikap menerima perbedaan pendapat dan menghadapinya secara toleran. Dengan sikap toleransi akan sangat bisa meminimalisir adanya konflik. Tawazzun sebagai sikap yang mampu memperhitungkan berbagai sudut pandang yang kemudian mengambil posisi yang seimbang dan proposional yang tidak terjebak pada titik-titik yang ekstrim pada pihak

16 Tim PWNU Jawa Timur, Aswaja An-Nahdliyah Ajaran Ahlussunah Wa Al-Jamaah yang Berlaku di Lingkungan Nahdlatul Ulama (Surabaya: Khalista, 2007), 57. 
yang berkonflik. Amar ma'ruf nahi munkar mengajak kepada hal kebaikan dan mencegah adanya kemunkaran. Amar ma'ruf nahi munkar ditujukan kepada para penyebar permusuhan, kebencian serta penghancur keharmonisan ditengah-tengah masyarakat atau kelompok.

Dengan menerapkan sikap-sikap diatas, sikap yang diajarkan Ahlussunnah Wal Jamaah dalam menghadapi berbagai keragaman, sikap Tawassuth, I'tidal, Tasammuh, Tawazzun, dan Amar Ma'ruf Nahi Munkar diharapkan akan mampu meminimalisir serta mencegah adanya suatu konflik yang terjadi dalam suatu kelompok termasuk dalam dunia pendidikan.

\section{E. Kesimpulan}

Konflik merupakan kondisi yang timbul dari ketidakcocokan atau pertentangan yang berpengaruh terhadap pihak-pihak yang terlibat baik pengaruh positif ataupun pengaruh negatif. Terdapat dua pandangan terkait dengan akibat atau pengaruh adanya konflik. Pandangan pertama beranggapan bahwa konflik dan merupakan suatu gejala yang membahayakan dan pertanda instabilitas lembaga. Implikasinya, manakala suatu lembaga pendidikan sering memiliki konflik, berarti lembaga tersebut semakin tidak stabil dan rentan akan bahaya sehingga harus segera diatasi. Sebaliknya, pandangan kedua beranggapan bahwa konflik itu menunjukkan adanya dinamika dalam organisasi, yang bisa mengantarkan pada kemajuan. Apabila dalam lembaga tidak ada konflik, justru ini menunjukkan tidak ada dinamika sama sekali yang berarti jauh dari realisasi kemajuan, dengan demikian konflik juga harus dikelola dengan baik.

Ada beberapa usaha yang dapat dilakukan dalam mengelola konflik sebagaimana konsep yang diberikan oleh pendidikan Islam. Antara lain yang sudah sering diterapkan di lembaga pondok pesantren yaitu silaturahmi, bahts al masaail, tabaayun, hakam, dan ishlaah. Sedangkan kunci utama agar jangan sampai muncul adanya konflik adalah dengan menekan kemarahan sedini dan sekecil mungkin. Kemudian dalam Ahlussunnah Wal Jamaah juga mengajarkan sikap dalam menghadapi berbgaia keberagaman yang bisa memicu munculnya suatu konflik yaitu dengan bersikap Tawassuth, I'tidal, Tasammuh, Tawazzun dan Amar Ma'ruf Nahi Munkar. 
JURNAL PIWULANG, Vol. 2 No. 1 September 2019, 11-24

\section{DAFTAR PUSTAKA}

Asnawir, Manajemen Pendidikan (Padang: IB Press, 2006).

Farchan, Hamdan dan Syarifuddin, Titik Tengkar Pesantren Resolusi Konflik Masyarakat Pesantren, (Yogyakarta: Pilar Religia, 2005).

Gibson, James, Organization, Behavior, Sructures, Processor, (Boston: Mc Grawhill, 2004).

Hanson, Educational Administration and Organizational Behavior, (Allyn and Bacon, Boston, 1990).

Mulyasa, Menjadi Kepala Sekolah Profesional, Dalam Konteks Menyukseskan $M B S$ dan KBK, (Bandung: PT Remaja Rosdakarya, 2003).

Rahim, Afzalur, Managing Conflict in Organization, (Praeger, New York, 1986).

Robbins, SP, Organizational Behaviour, (Prentice Hall, Siding, 1979).

Siroj, Said Aqil, Islam Sumber Inspirasi Budaya Nusantara Menuju Masyarakat Mutamaddin, cetakan ke II (Jakarta Pusat: LTN NU, 2015).

Sulistyorini dan Fathurrohman Muhammad, Esensi Manajemen Pendidikan Islam Pengelolaan Lembaga untuk Meningkatkan Kualitas Pendidikan Islam (Yogyakarta: Teras, 2014).

Tim PWNU Jawa Timur, Aswaja An-Nahdliyah Ajaran Ahlussunah Wa AlJamaah yang Berlaku di Lingkungan Nahdlatul Ulama (Surabaya: Khalista, 2007).

Wahyosumidjo, Kepemimpinan Kepala Sekolah, Tinjauan Teoretik dan permaslahannya, (Raja Gafindo Persada, Jakarta, 2002). 